\title{
Mobile Applications to Improve English Writing Skills Viewed from Critical Thinking Ability for Pre-Service Teachers
}

\author{
https://doi.org/10.3991/ijim.v14i07.11900 \\ Haerazi ${ }^{\bowtie}$, I Made Permadi Utama, Heri Hidayatullah \\ Mandalika University of Education, West Nusa Tenggara, Indonesia \\ alhaerazi83@gmail.com
}

\begin{abstract}
This study was aimed at investigating; (1) the pre-service teachers used the MobApps (WhatsApp, U-Dictionary, and Email) to participate in mobile-assisted language learning (MALL) viewed from the critical thinking ability in the teaching of writing skills and; (2) the effectiveness of the Mobile-assisted language learning (MALL) towards pre-service teachers' writing skills in relation to critical thinking ability. This study was a mixed method using the concurrent embedded strategy. The researchers involve qualitative strategies and quantitative strategies. Both kinds of data are collected simultaneously. This study was conducted in the English language education departments of FPBS IKIP Mataram, Indonesia. 58 pre-service teachers were involved in this study. The qualitative data were attained from pre-service teachers attending the writing classes using observation sheets. Meanwhile, the quantitative data were gained from experimental design through a nonequivalent control-group design. The groups were evaluated by using a writing test and a critical thinking test. The results showed that the pre-service teachers conducted a discussion of what they have to write. The learning activities are done under several stages. The end of this is that the pre-service teachers are able to create a complete descriptive text. Besides, the use of the MALL model was more effective than non-mobile learning to improve pre-service teachers' writing skills viewed from critical thinking skills.
\end{abstract}

Keywords-MobApps, MALL model, writing skill, critical thinking skill

\section{Introduction}

The use of mobile applications (hereafter called MobApps) has been increasingly applied in English as Foreign Language (EFL) teaching around in the world. MobApps provide some applications that are utilized by English lecturers or teachers for improving pre-service teachers' and students' language skills. It is showed that the surge of interest in any kind of MobApps has taken a place in the EFL teaching and learning modes [1] [2]. Therefore, the use of MobApps gives great changes in English education in terms of the cognition of teachers and students, instructional materials design, the role of students and teachers in practice, and evaluation and testing [3]. 
In EFL teaching and learning, the language skills need appropriate teaching media so that the pre-service teachers acquired those effectively and fast. In addition, the teaching media should facilitate them to involve in an effective language interaction. For instance, mobile-assisted learning is used to help prospective teachers to enhance their reading fluency [4], online writing is applied in conducting extensive reading strategy [5], new application technologies are used for activating active engagement and deep learning [6], smartphones are utilized for online English language testing [7] [8], and an ERF online system is used to improve student-teacher learning interaction [9] [10]. The development of new technologies has influenced the way the lecturers in higher education treat pre-service teachers' language skills (speaking, listening, reading, and writing).

According to [11], the development of web-based learning and mobile-assisted language learning (MALL) can support students' learning and online interaction because they can create instructional content in a digital form that provides a wider autonomous space. In addition, students can utilize multimodal formats based on the content and product they create [12]. In Indonesian higher education institutions, lecturers are demanded to improve their professional competence in using any new technologies in applying any instructional model in their teaching and learning practice. As stated in [13], the advancement of ICT inspires lecturers, language teaching experts, and practitioners to develop their instructions, teaching media, and materials such as flipped learning [14], MALL modes [15], Weibo and WeChat mobile devices [16].

A mobile phone is a daily need for pre-service teachers and it can be used to support English language learning and teaching. As stated in [3] [17], mobile phones with its various applications excel in terms of providing communication and information tools. Besides, the mobile phone offers users' easy access to language learning, anywhere or anytime [18]. In a nutshell, the mobile phone has no doubt to provide features such as texting, camera, audio, video, google searching, etc. It gives benefits for lecturers or teachers to perform their learning materials and tasks [19] [20] [21].

English language learning has moved to a digital realm. Writing skills are potential to be improved by using MobApps software tools. Writing activities can be done by pre-service teachers much more using MobApps tools. Grigoryan [22] argues that the advancement of digital software tools nowadays is able to help students practice much more to write. The access and use of mobile technologies for doing interaction, communication, and getting and share information are spread out [23]. It is possible for a lecturer to lead pre-service teachers in doing writing activities. It also enables to exploit the various genres such as genre structure, the text unit, and the graphology aspects [24].

To operate the various aspects of genres, pre-service teachers should have critical thinking skills. Critical thinking is necessary for pre-service teachers during the learning process, in information seeking, and cognitive development. Aghajani and Gholamrezapour [25] state that critical thinking is an ability to evaluate and regulate useful and purposeful arguments in the form of an interpretation, analysis, evaluation, and inference. The power of critical thinking gives effect on reading comprehension [26], [27], [28], [29] and writing skills [30] [31]. Besides, the dominant thinking skill strongly needed in the $21^{\text {st }}$-century learning is critical thinking skills [32]. Therefore, 
the use of MobApps mediates pre-service teachers to enhance their writing skills viewed from the level of critical thinking skills.

In this study, lecturers applied MobApps, namely WhatsApp, U-Dictionary, and Email. These media are used to improve pre-service teachers' writing skills. The writing skill of students was chosen in this study because this skill was assumed as the most difficult language skill for higher education students. Besides, the pre-service teachers need to improve the crucial skill of the $21^{\text {st }}$-century learning skill which is critical thinking skill. Given the fast development of Mobile-phone usage, the notion of critical thinking skills in EFL classes has engrossed researchers and practitioners.

Based on the objective of this study, there were several questions it sought to elaborate; how do the pre-service teachers use WhatsApp, U-Dictionary, and Email to participate in mobile-assisted language learning (MALL) viewed from the critical thinking ability in the teaching of writing skills?; and does the Mobile-assisted language learning (MALL) have a significant effect on pre-service teachers' writing skills in relation to critical thinking ability?

The novelty of this study lies in the use of mobile applications in the form WhatsApp, U-Dictionary, and Email in the teaching of writing skills viewed from pre-service teachers' critical thinking level at the English language education department. The critical thinking ability is considered as one of the crucial skills in $21^{\text {st }}$-century learning. In the context of EFL learning, mobile-assisted language learning is employed as the instructional model to teach writing skills. Therefore, the application of mobile-assisted language learning using MobApp is integrated into the teaching of writing skill in relation to critical thinking level.

\section{$2 \quad$ Literature Review}

This part presents some theoretical concepts supporting the implementation of the MobApps to improve pre-service teachers' critical thinking skills viewed from the critical thinking level at the English language department, Indonesia. The concepts include the issues of mobile-assisted language learning, critical thinking skills, and teaching writing skills at higher education. The issues of those can be elaborated as follows.

\subsection{Mobile-assisted language learning}

In higher education, lecturers have got benefits from the development of information and communication technologies (ICT). Internet connection to access certain learning materials and tasks can be achieved through mobile phones for English language teaching and learning. Besides, lecturers develop a certain instructional model based on mobile application tools, namely mobile-assisted language learning (MALL) model. As stated in [15] [33], the MALL model has been a promising issue among foreign language lecturers because this model gives big chances for them to explore smartphone features to facilitate their students to learn. When the MobApp use for language learning is properly employed, the pre-service teachers reap many features such as 
WhatsApp, Dictionary software, Email, Facebook, Youtube, and Instagram. It can be operated for teaching writing, speaking, reading and listening.

Lys [34] argues that MALL is an instructional model utilizing a number of electronic devices for information and communication in language teaching and learning. The electronic devices are then called gadgets or iPod. These MobApps tools have proven to become outstanding learning media for creating learning materials and proper content [35]. Additionally, the MALL model can support pre-service teachers to operate those devices anywhere and anytime. It involves pre-service teachers in independent learning. According to [16] [36], MALL is seen as an informal learning model that caters for the requirements of the contextual language learning, situated learning [37], and blended learning.

As a form of learning, the MALL model involves learning facilitated by mobile devices. In other words, mobile learning refers to the acquisition of language through MobApps devices in order to learn. As stated in [38] the MALL model caters to continuous chances to extend spaces and times for pre-service teachers to learn. In learning practice, the use of the MALL model recently prioritizes offline dictionary use, Pdf reader application use, audio-video player use, and Audio-video recorder use such as Podcasts that enable pre-service teachers to access contents and useful learning topics [39]. In this study, mobile devices such as WhatsApp, U-Dictionary (Offline), and Email are employed to improve pre-service teachers' writing skills in the English language department at higher education.

\subsection{Teaching writing skill in higher education}

Teaching writing skills in Indonesian higher education happens in the form of discrete learning [40]. It means that the four language skills are taught in a different semester and the separated skills, not in the integrative ways. It is aimed at strengthening pre-service teachers' knowledge and skills for each language skill. In the context of teaching and learning, writing skills are taught in various ways including the use of social media. For instance, blogs, podcasts, and Facebook are designed to practice writing [41] in higher education. The writing aspects addressed by using electronic media are to improve writing performance [42] [43] [44], to practice writing in wider communication using email [45], to enhance syntactic complexity [46], grammatical competence [46], and to alleviate writing anxiety and promote writing skills among gifted learners [47]. In other words, teaching writing skills can be done in various learning models with various teaching media in this digital realm. The aspects of writing skills addressed include contents, organization, vocabulary, grammar, and mechanics. In this study, the MobApps of WhatsApp, U-Dictionary, and Email are employed to help preservice teachers develop those of writing skills.

\subsection{Critical thinking skills}

Critical thinking skills are parts of higher-order thinking skills reflecting on 21 stcentury learning skills. As stated in [48], critical thinking skills include the skills of analyzing arguments, making inferences in inductive or deductive reasoning, 
evaluating, and making solving problems. Furthermore, Kim et al. [49] argue that critical thinking involves learners to think in purposeful, reasonable, evaluative, and reflective ways in the problem-solving process. In the EFL learning and teaching context, critical thinking skills are needed to encourage pre-service teachers to think highly. It helps them to learn effectively and accurately. Nevertheless, numerous studies in higher education have found that lecturers and teachers lack deep knowledge and understanding of critical thinking skills on how to incorporate those into courses so that learners can develop their potentials of those [50] [51] [52].

\section{$3 \quad$ Research Method}

This study employed a mixed-method using the concurrent embedded strategy. Concurrent embedded strategy includes one data collection phase [53]. Researchers involve qualitative strategies, particularly observation sheets during the learning process, and quantitative strategy, in the form of experimental design. Both kinds of data are collected simultaneously. This study was focused on how the pre-service teachers use WhatsApp, U-Dictionary, and Email to participate in mobile-assisted language learning (MALL) viewed from the critical thinking ability in the teaching of writing skills; and whether the Mobile-assisted language learning (MALL) using WhatsApp, U-dictionary, and Email has a significant effect towards pre-service teachers' writing skills in relation to critical thinking ability.

This study was conducted in the English language education departments of FPBS IKIP Mataram, Indonesia. 58 pre-service teachers were involved in this study. The qualitative data were attained from pre-service teachers attending the writing classes using observation sheets. Meanwhile, the quantitative data were gained from experimental design through a nonequivalent control-group design. The pre-service teachers were divided into two groups, namely the experimental and control group. The group one was treated by using the MALL model while the second one was subjected to a non-mobile learning model. Besides, the groups were assessed using a writing test to know pre-service teachers' writing achievement and a critical thinking test to find out the level of pre-service teachers' critical thinking achievement.

The data obtained from qualitative strategy were analyzed in several stages, namely data description, data categorization, data coding, and interpretation subjected to content analysis. Meanwhile, the data collected from the quantitative strategy were analyzed in the descriptive statistical and inferential analysis. The descriptive analysis was aimed at finding out the pre-service teachers' mean, mode, and standard deviation scores of writing achievement, while inferential analysis was subjected to answer the second research question of this study. It was analyzed using a multifactor analysis of variance (ANOVA). The normality test was done using a One-sample KolmogorovSmirnov formula and the homogeneity of the variance data was analyzed using Levene test. The data had the same variance because the sig. probability among data was higher than sig. level 0.05. Moreover, the computation of the ANOVA analysis was conducted utilizing the IBM SPSS 21.0. This was used to know the significant difference between 
the two learning models applied and critical thinking skills. Finally, the interpretation of whether the data are in supporting or not was carried out in this study.

\section{$4 \quad$ Research Finding and Discussion}

\subsection{Research findings}

This study was aimed at investigating pre-service teachers' experience in using MobApps to participate in MALL (mobile-assisted language learning); to produce and share generic structures and language features of descriptive texts, to interact and collaborate to write. Therefore, the research findings are administered in two sections in line with the research questions. The first part is about pre-service teachers' experience in operating MobApps (WhatsApp, U-Dictionary, \& Email) usage to participate in the MALL model, while the second part is about the effect of MALL model towards their achievement of writing skills.

The researchers conducted observation in the writing classes to know students' activities and participation using the WhatsApp. Pre-service teachers are involved in writing activities. The results then are written and submitted via the WhatsApp tool by each pre-service teacher. The lecturer makes a WhatsApp group and pre-service teachers interact and discuss each other in the group. The tool of U-Dictionary is used to help pre-service teachers' English writing if they do not know some vocabulary and spelling. Also, they can translate from their language into the English word. Besides, the focus group discussion was conducted to investigate their knowledge dealing with the use of WhatsApp features. At the end of this, the pre-service teachers are asked to send the complete text via Email. The Email, WhatsApp, and U-Dictionary are, of course, installed on their mobile. The sequences of pre-service teachers' work can be seen in Table 1 as follows. 
Table 1. Sequence of Pre-service Teachers in Using MobApps

\begin{tabular}{|c|l|l|}
\hline No & \multicolumn{1}{|c|}{ Learning Activities } & \multicolumn{1}{|c|}{ Pre-service Teachers Activities } \\
\hline 1 & $\begin{array}{l}\text { Building knowledge of the text be- } \\
\text { ing written by learners }\end{array}$ & $\begin{array}{l}\text { Pre-service teachers discuss the generic structures of descrip- } \\
\text { tive texts. }\end{array}$ \\
\hline 2 & $\begin{array}{l}\text { Discussion on social media } \\
\text { WhatsApp for the generic structure } \\
\text { of descriptive texts }\end{array}$ & $\begin{array}{l}\text { Pre-service teachers exchange knowledge, experience, and } \\
\text { opinion on the WhatsApp dealing with descriptive texts. }\end{array}$ \\
\hline 3 & $\begin{array}{l}\text { Discussion on social media } \\
\text { WhatsApp for an introductory para- } \\
\text { graph of the descriptive text }\end{array}$ & $\begin{array}{l}\text { Pre-service teachers practice writing simple introductory para- } \\
\text { graphs. } \\
\text { Pre-service teachers give feedback about each simple introduc- } \\
\text { tory paragraph on social media WhatsApp. } \\
\text { Pre-service teachers determine the topic sentence of each intro- } \\
\text { ductory paragraph on social media WhatsApp. }\end{array}$ \\
\hline 4 & $\begin{array}{l}\text { Discussion on social media } \\
\text { WhatsApp for the body of text in the } \\
\text { descriptive text }\end{array}$ & $\begin{array}{l}\text { Pre-service teachers practice writing simple main paragraphs } \\
\text { of a descriptive text. } \\
\text { Pre-service teachers give feedback on each simple main para- } \\
\text { graph of a descriptive text on social media WhatsApp. } \\
\text { Pre-service teachers determine the proper introductory para- } \\
\text { graph for the main paragraph of descriptive texts on social me- } \\
\text { dia WhatsApp. }\end{array}$ \\
\hline 5 & $\begin{array}{l}\text { Practice writing a complete descrip- } \\
\text { tive text on social media WhatsApp. }\end{array}$ & $\begin{array}{l}\text { Pre-service teachers practice writing a complete descriptive } \\
\text { text on social media WhatsApp. } \\
\text { Pre-service teachers conduct peer review of a complete de- } \\
\text { scriptive text on social media WhatsApp. } \\
\text { Pre-service teachers determine the language features of de- } \\
\text { scriptive texts. }\end{array}$ \\
\hline $\begin{array}{l}\text { Email used to accomplish and sub- } \\
\text { mit the complete descriptive text. }\end{array}$ & $\begin{array}{l}\text { Pre-service teachers discuss first the complete descriptive text } \\
\text { and submit it via email to the writing lecturer. } \\
\text { The lecturer gives feedback of the pre-service teachers' tasks } \\
\text { and sends it back to them. }\end{array}$ \\
\hline
\end{tabular}

Table 1 presented the pre-service teachers' activities and participation using WhatsApp in the form of mobile-assisted language learning in the teaching of writing skills. The pre-service teachers conducted a discussion of what they have to write on social media. The learning activities are done under several stages in the lecturer's guidelines. The end of this is that the pre-service teachers are able to create a complete descriptive text. The topics suggested are objects around them such as families, campuses, traditional food, traditional Sasaq houses, and historical building in Indonesia.

In the discussion session, pre-service teachers exchange their learning experience and opinions on mobile phones with MobApps like WhatsApp, U-Dictionary, and Email for supporting their learning. Most of them explored other model texts or genres on social media WhatsApp. The notion of WhatsApp usage for language learning was not functioned maximally in practicing to write. The finding showed that pre-service teachers have got an experience of how WhatsApp, U-Dictionary, and Email could be used to support their learning activities, particularly for improving writing skills.

Dealing with the mobile-assisted language learning (MALL) model, the lecturer and pre-service teachers conducted the learning activities well because this model required the lecturer to operate some mobile applications (MobApps) in classroom learning. The learning stages of the MALL model were employed well so the lecturer felt easy to control pre-service teachers' writing activities. Besides, pre-service teachers are able to 
give comments, questions, and feedback for their peers profusely. Additionally, the preservice teachers' achievement in writing was improved. It means that the MALL model was effective to teach writing skills for pre-service teachers of the English language department at IKIP Mataram. The finding of their achievement can be seen in Table 2 as follows.

Table 2. Pre-Service Teachers' Writing Achievement

\begin{tabular}{|c|c|c|c|c|c|}
\hline \multirow{2}{*}{\multicolumn{2}{|c|}{$\begin{array}{c}\text { Learning Model Viewed from Critical } \\
\text { Thinking Skill }\end{array}$}} & \multirow{3}{*}{$\begin{array}{l}\text { Mean } \\
76.130 \\
\end{array}$} & \multirow{3}{*}{$\begin{array}{c}\text { Std. Error } \\
.590\end{array}$} & \multicolumn{2}{|c|}{$\mathbf{9 5 \%}$ Confidence Interval } \\
\hline & & & & \multirow{2}{*}{$\begin{array}{c}\text { Lower Bound } \\
74.946\end{array}$} & \multirow{2}{*}{$\frac{\text { Upper Bound }}{77.313}$} \\
\hline & MALL Model & & & & \\
\hline Learning Model & Non-Mobile Model & 73.568 & .612 & 72.342 & 74.795 \\
\hline \multirow{2}{*}{ Critical Thinking Skill } & High & 73.957 & .523 & 72.909 & 75.005 \\
\hline & Low & 75.742 & .670 & 74.398 & 77.086 \\
\hline \multirow[t]{2}{*}{ Mall Model } & High & 75.176 & .759 & 73.654 & 76.699 \\
\hline & Low & 77.083 & .904 & 75.271 & 78.896 \\
\hline \multirow[t]{2}{*}{ Non-Mobile Model } & High & 72.737 & .718 & 71.297 & 74.177 \\
\hline & Low & 74.400 & .990 & 72.415 & 76.385 \\
\hline
\end{tabular}

The pre-service teachers were divided into two groups. One group was taught by using Mobile-assisted language learning (MALL) and the second one was taught using a traditional learning model or non-mobile-assisted learning model. In this study, the critical thinking skill was assumed as an attribute variable that influences the pre-service teachers' writing achievement. Based on the research finding, the writing achievement of pre-service teachers treated using the MALL model (76.130) was effective than that of them treated using non-mobile-assisted learning (73.568). The MALL model has a significant effect on pre-service teachers' writing skills viewed from the level of critical thinking skills. The summary of the ANOVA test can be drawn in Table 3 as follows.

Table 3. The Summary of ANOVA Test

\begin{tabular}{|l|c|c|c|c|c|}
\hline \multicolumn{1}{|c|}{ Source } & $\begin{array}{c}\text { Type III Sum of } \\
\text { Squares }\end{array}$ & df & Mean Square & F & Sig. \\
\hline Corrected Model & $145.925^{\mathrm{a}}$ & 3 & 48.642 & 4.961 & .004 \\
\hline Intercept & 304076.887 & 1 & 304076.887 & 31012.345 & .000 \\
\hline Learning Model & 89.029 & 1 & 89.029 & 9.080 & .004 \\
\hline CT & 43.235 & 1 & 43.235 & 4.409 & .040 \\
\hline Learning Model * CT & .201 & 1 & .201 & .021 & .887 \\
\hline
\end{tabular}

\subsection{Discussion}

This study falls into the category of smartphone trends in EFL teaching and learning in Higher education. It investigates the pre-service teachers' experience to participate in the mobile-assisted language learning (MALL) activities in writing classes. In addition, this study was aimed at finding out the effectiveness of the MALL model towards pre-service teachers' writing skills viewed from critical thinking skills. In higher education, a smartphone or mobile phone is a need to communicate and interact with pre- 
service teachers. It is also the most frequently ICT tool used by them. Therefore, it can be utilized to support English language learning, particularly for improving writing skills. It was in line with [3] [17] that mobile phone was a daily need for pre-service teachers and it also excelled in terms of communication and information delivery.

The pre-service teachers participated in MALL activities for improving their writing skills. They have the ability to operate the WhatsApp device, U-Dictionary, and Email. It was proven with their activities to accomplish each generic structure of descriptive texts. They are able to interact and also give correction among them in the WhatsApp group. For instance, when some pre-service teachers posted an introductory paragraph of the descriptive text, the other pre-service teachers give comments on grammatical structures and vocabulary usage. They felt free to share their opinions based on their knowledge of descriptive texts. It was enforced with Handayani's finding [54] that using social media enables language learners to exchange information for language learning purposes autonomously. Besides, pre-service teachers made various efforts independently to improve their learning activities in the class and outside the class. It is also supported by Syarofi et al. [55] that the use of social media such as a Weblog device can help students to create and share their own contents which suit their learning needs. Therefore, in this study pre-service teachers exhibited their abilities to create content and interact with their peers on the particular generic structure of descriptive texts and language features of paragraphs using the WhatsApps device.

Before using WhatsApp, the pre-service teachers are allowed to discuss the learning topic with their groups in the class. It is seen that pre-service teachers are active and enthusiastic in giving opinions. It aims to promote their autonomy in learning writing [56]. When this discussion happens, few pre-service teachers still do not try to give comments but most pre-service teachers involve identifying the errors and give a solution on how the language errors should be corrected. Some of the pre-service teachers also address questions regarding the use of grammar in the descriptive text. In addition, not a few of pre-service teachers debate with their peers when they have different ideas of composing the descriptive text. They learn in their own ways because giving learners with situational interest encourages them to learn with their will [57]. In this condition, the lecturer supervises them with a better suggestion of it. Shortly, the participation of pre-service teachers in the implementation of the MALL model is very active.

The use of the MALL model facilitates pre-service teachers to build their knowledge of the text in the class and at home, all pre-service teachers post their work and share comments with each other. It seems that online learning helps them diminish their workload [58]. It provides valuable guidance for pre-service teachers and lecturers. For instance, for the pre-service teachers who do not post their works in WhatsApps, the lecturer asks them to show their writing tasks and give them feedback immediately in the class. In this situation, giving feedback also whether through WhatsApps or in the class makes the learning process effective. It is in line with [59] [60] who found that feedbacks on writing such as content, organization, grammar, and have a positive effect for pre-service teachers.

Pre-service teachers create a complete descriptive text in the form of good content, organization, grammar, and vocabulary through WhatsApp writing activities. They can utilize their critical thinking as one of the higher-order thinking skills in perceiving the 
complete generic structure of the descriptive text. It seems when they conducted active learning through the WhatsApps device. Active learning helps them to think deeply and logically [61]. Most students are very accustomed to discuss and expose their ideas in the group. Nevertheless, few students seem reluctant and hesitated to participate in learning activities at the beginning. However, they gradually start contributing to the WhatsApp group discussion. For instance, they are initially not clear about the generic structures, language features, and common tenses used in the descriptive text. Outstanding pre-service teachers help weaker student-teachers and they deepen their understanding by sharing each other. The U-Dictionary device also is useful to check their spelling and to translate difficult words. In this situation, they perform to think more deeply and logically.

The pre-service teachers' critical thinking skills can be improved through the use of the WhatsApp device in terms of the MALL model both in the high-level category and low-level category of the English language department in higher education. The instructional materials provided for students include wedding ceremonies, historical buildings, traditional houses, and traditional music. The local cultures are chosen to help student-teachers practice writing. According to [62] the local culture phenomena can motivate learners to learn. These learning materials are presented during the implementation of a mobile-assisted language learning (MALL) model. In Addition, it would be easy to elaborate and describe in the form of the descriptive text. In the learning process, the MALL model involves the pre-service teachers to perform their higherorder thinking skills such as analyzing, evaluating and creating process.

In discussing an introductory paragraph of the descriptive text, pre-service teachers conduct an analysis of the topic and the topic sentence. They post it in the group. Most pre-service teachers do an evaluation of the paragraph. It is seen from the discussion and comments happening in the WhatsApps group. The active learning of this helps them to create a simple introductory paragraph of the descriptive text. This finding is enforced by Hidayati et al. [63] who found the learning interaction in digital devices such as Website, Instagram, and WhatsApp can help learners to develop their critical thinking skills. Therefore, critical thinking plays an important role in sorting out the various alternatives so that the most appropriate argument can be presented in a complete descriptive text.

Compared with the MALL model, the non-mobile learning model also has a positive effect towards pre-service teachers' writing skills. Nevertheless, non-mobile learning doesn't seem as effective as the MALL model does to improve writing skills viewed from critical thinking skills. Table 3 indicated that the learning model (MALL and nonmobile learning) has a significant difference. The column of the learning model was lower (0.004) than sig. level 0.05. Based on the descriptive analysis in Table 2, the MALL model was more effective to teach writing classes using the non-mobile learning model viewed from critical thinking skills. 


\section{Conclusion}

The use of MobApps in teaching English as a foreign language helps pre-service teachers activate their potential and competences in acquiring linguistic competences, critical thinking skills, creativities, and classroom interactions. This study was focused on investigating the pre-service teachers' experience to participate in the use of mobileassisted language learning (MALL) models in the teaching of writing skills. Besides, this study was carried out to find out the effectiveness of the MALL model to improve student-teachers' writing skills viewed from critical thinking skills. The pre-service teachers' experiences to participate using the MALL model were able to interact and communicate actively through the WhatsApp device. They seem to be able to perform their linguistic competences in writing descriptive paragraphs. Besides, they construct active learning using U-dictionary to confirm the spelling and meaning. At the end of this activity, they submit the final version of the descriptive text through Email to the lecturer. Then, the lecturer gives feedback on the writing.

The implementation of the MALL model in writing classes was able to improve preservice teachers' writing skills. It was proven with the average score of student-teachers who were treated using the MALL model was higher than the non-mobile learning model. Additionally, the pre-service teachers' critical thinking was improved. The local cultures provided as the instructional materials facilitated them to practice writing easily. The outstanding learners help weaker student-teachers and they can deepen their understanding of the generic structures of the descriptive text by sharing each other.

\section{References}

[1] Wenming, Z., \& Erwen, Z. (2018). On China's English teaching reform: From micro-lesson and MOOCS to flipped class. International Journal of Emerging Technologies in Learning, 13(1), 220-229. https://doi.org/10.3991/ijet.v13i01.7465

[2] Liu, R. Q. (2014). Foreign languages education and studies in the era of big data. Contemporary Foreign Languages Studies, 14(7), pp. 1-6.

[3] Yudhiantara, R. A., \& Nuryantini, A. Y. (2019). Promoting mobile collaborative language learning in Islamic higher education. Journal on English as a Foreign Language, 9(1), 87106. https://doi.org/10.23971/jefl.v9i1.961

[4] Hendriwanto \& Kurniati, U. (2019). Building reading fluency with mobile assisted extensive reading. International Journal of Interactive Mobile Technologies (iJEM), 13(6) 40-52. https://doi.org/10.3991/ijim.v13i06.9799

[5] Zhong, S, Xian, M. Y, \& KeKang, H. (2016). An extensive reading strategy to promote online writing for elementary students in the 1:1 digital classroom. Computer Assisted Language Learning, 29(2) 398-412, https://doi.org/10.1080/09588221.2014.974860

[6] Barr, M. L. (2017). Encouraging college student active engagement in learning: Student response methods and anonymity. Journal of Computer Assisted Learning, 33(6), 621-632. https://doi.org/10.1111/jcal.12205

[7] Solihati, N., \& Mulyono, H. (2018). Designing and evaluating the use of smartphones to facilitate online testing in second-language teacher education (SLTE): An auto-ethnographic study. International Journal of Emerging Technology (iJET), 13(1) pp 124-137. https://doi.org/10.3991/ijet.v13i01.7683 
[8] Mulyono, H. (2016). Using quipper as an online platform for teaching and learning English as a foreign language. Teach.English with Technology, 16(1), pp. 59-70.

[9] Su, C. Y. (2017). Investigating the effectiveness of an interactive IRF-based English grammar learning system. International Journal of Emerging Technologies in Learning, 12(11), 63-82. https://doi.org/10.3991/ijet.v12i11.7036

[10] Hu, J. S. \& Jin, Y. (2015). Theories and practices in the integration of education technologies and English courses, China Educational Technology, 48(4) pp. 24-31

[11] Satar, H. M., \& Akcan, S. (2018). Pre-service EFL teachers' online participation interact ion, and social presence. Language Learning \& Technology, 22(1), 157-183.

[12] Blake, R. (2016). Technology and the four skills. Language Learning \& Technology, 20(202), 129-142. Retrieved from http://llt.msu.edu/issues/june2016/blake.pdf

[13] Fauzan, A., \& Ngabut, M. N. (2018). EFL students' perception on flipped learning in writing class. Journal on English as a Foreign Language, 8(2), 115. https://doi.org/10.23971/ jefl.v8i2.792

[14] Kukulska-Hulme, A., \& Viberg, O. (2018). Mobile collaborative language learning: State of the art. British Journal of Educational Technology, 49(2), 207-218. https://doi.org/10. $1111 /$ bjet. 12580

[15] Shadiev, R., Hwang, W. Y., \& Huang, Y. M. (2017). Review of research on mobile language learning in authentic environments. Computer Assisted Language Learning, 30(3-4), 284303. https://doi.org/10.1080/09588221.2017.1308383

[16] Zhang, Y. \& Zuo, L. (2019). College English teaching status and individualized teaching design in the context of mobile learning. International Journal of Emerging Technologies in Learning, 14(12), 85-96. https://doi.org/10.3991/ijet.v14i12.10704

[17] Yudhiantara, \& Nasir. (2017). Toward mobile-assisted language learning (MALL): Reaping mobile phone benefits in classroom activities. Register Journal, 10(1), 12-28. http://dx.doi.org/10.18326/rgt.v10i1.12-28. https://doi.org/10.18326/rgt.v10i1.813

[18] Wang, S., \& Smith, S. (2013). Reading and grammar learning through mobile phones. Language Learning \& Technology, 17(3), 117-134.

[19] Thomas, K., \& Munoz, M. A. (2016). Hold the phone! high school students' perception of mobile phone integration in the classroom. American Secondary Education, 44(3), 19-37.

[20] Liu, M., Scordio, R., Renata, G., Navarete, C., Yujung, K., \& Lim, M. (2015). A look at research on mobile learning in k-12 education from 2007 to the present. Journal of Research on Technology in Education, 46 (4), 325-372

[21] Oyewusi, F., \& Ayanlola, A. O. (2014). Effect on mobile phone use on reading habit of private secondary school student in Oyo state Nigeria. School Libraries Worldwide, 20(1), $116-127$

[22] Grigoryan, T. (2018). Investigating digital native female learners" attitudes towards paperless language learning. Research in Learning Technology, 26, 19-37 https://doi.org/10. 25304/rlt.v26.1937

[23] Uwizeyimana, V. (2018). Digital native (ness), mobile technologies and language proficiency in Rwanda. REGISTER Journal, 11(2), pp 121-138. https://doi.org/10.18326/rgt. v11i2.121-138

[24] Noriega, H. S. R. (2016). Mobile learning to improve writing in ESL teaching. 27(2) pp 182202. http://dx.doi.org/10.15639/teflinjournal.v27i1/182-202

[25] Aghajani, M. \& Gholamrezapour, E. (2019). Critical thinking skills, critical reading and foreign language reading anxiety in Iran context. International Journal of Instruction, 12(3), 219-238. https://doi.org/10.29333/iji.2019.12414a 
[26] Husna, N. (2019). Developing students' critical thinking through an integrated extensive reading program. TEFLIN Journal, 30(2), 212-223. http://dx.doi.org/10.15639/teflinjournal.v30i2/212-230

[27] Eftekhary, A. A., \& Kalayeh, K. B. (2014). The relationship between critical thinking and extensive reading on Iranian intermediate EFL learners. Journal of Novel Applied Sciences, $3(6), 623-628$

[28] Tabačková, Z. (2015). Outside the classroom thinking inside the classroom walls: Enhancing students' critical thinking through reading literary texts. Procedia-Social and Behavioral Sciences, 18(3), 726-731 https://doi.org/10.1016/j.sbspro.2015.04.042

[29] Zhou, J., Jiang, Y., \& Yao, Y. (2015). The investigation on critical thinking ability in EFL reading class. English Language Teaching, 8(1), 83-94.

[30] Pu, S., \& Evans, M. (2019). Critical thinking in the context of Chinese postgraduate students' thesis writing: a positioning theory perspective. Language, Culture and Curriculum, 32(1), 50-62. https://doi.org/10.1080/07908318.2018.1442473

[31] Pei, Z., Zheng, C., Zhang, M., \& Liu, F. (2017). critical thinking and argumentative writing: Inspecting the association among EFL learners in China. English Language Teaching, 10 (10) pp 31-42. http://doi.org/10.5539/elt.v10n10p31

[32] Kharbach, M. (2012). The 21st century skills teachers and student need to have. Halifax: Creative Commons Attribution Mount Saint Vincent University.

[33] Kukulska-Hulme, A., \& Shield, L. (2008). An overview of mobile assisted language learning: From content delivery to supported collaboration and interaction. ReCALL, 20(03), 271-289.https://doi.org/10.1017/S0958344008000335

[34] Lys, F. (2013). The development of advanced learner oral proficiency using Ipads. Language Learning \& Technology, 17(173), 94-116. Retrieved from http://llt.msu.edu/issues/october2013/lys.pdf

[35] Arvanitis, P., Krystalli, P., \& Panagiotidis, P. (2016). Applications for mobile assisted language learning: A current field research. Proceedings of INTED2016 Conference 7th-9th March 2016, Valencia, Spain, (December 2017), 7645-7651. https://doi.org/10.21125/ inted.2016.0803

[36] Huang, R. T., Jang, S. J., Machtmes, K., Deggs, D. (2012). Investigating the roles of perceived playfulness, resistance to change and self-management of learning in mobile English learning outcome, British Journal of Educational Technology, 43(6): 1004-1015. https://doi.org/10.1111/j.1467-8535.2011.01239.x

[37] Wu, P. H., Hwang, G. J., Tsai, C. C., Chen, Y. C., \& Huang, Y. M. (2011). A pilot study on conducting mobile learning activities for clinical nursing courses based on the repertory grid approach. Nurse Education Today, 31(8): e8-e15. https://doi.org/10.1016/j.nedt.2010. $\underline{12.001}$

[38] McCaffrey, M. (2011). Why mobile is a must. Teaching in Higher Education Journal, 38(2), 21-22.

[39] McCarthy, S. (2005). Spoken internet to go: Popularization through podcasting. JALT CALL Journal, 1(2), 67-74. https://doi.org/10.29140/jaltcall.v1n2.r11

[40] Haerazi, Irwansyah, D., Juanda, \& Azis, Y. A. (2018). Incorporating intercultural competences in developing english materials for writing classes, Journal of Language Teaching and Research, 9(3) 540-547 https://doi.org/10.17507/jltr.0903.13

[41] Rodliyah, R. S. (2016). Using a facebook closed group to improve EFL students' writing. TEFLIN Journal, 27(1) pp 82-89. https://doi.org/10.15639/teflinjournal.v27i1/82-100

[42] Naba'h, A. A. (2013). The effects of using electronic dialogue journal on English writing performance of Jordanian students. International Arab Journal on e-Technology, 3(1), 3743. 
[43] Abdelrahman, O. N. B. (2013). Use of dialogue through e-mail technology in developing writing skills to English as a foreign language learners (EFL) at Al-Imam Mohammad Ibin Saud Islamic University. Journal of Educational and Psychological Sciences, 14(4), 665688. https://doi.org/10.12816/0013730

[44] Foroutan, M., Noordin, N. \& Gani, M. S. (2013). Use of e-mail dialogue journal in enhancing writing performance. Asian Social Science. 9(7), 208-217.

[45] Staton J., Shuy R. W., Peyton, J. K., \& Reed, L. (2005). Dialogue journal communications: Classroom, linguistic, social and cognitive views. Norwood, NJ: Ablex. https:// doi.org/10.1017/s0047404500014056

[46] Shang, H. (2007). An exploratory study of e-mail application on FL writing performance. Computer Assisted Language Learning, 20(1), 79-96. https://doi.org/10.1080/0958822060 1118479

[47] Thevasigamoney, A. F., \& Yunus, M. M. (2014). A glimpse into e-mail dialogue journal writing (EDJW) and writing anxiety among gifted learners. Procedia-Social and Behavioral Sciences, 123(20), 266 - 271. https://doi.org/10.1016/j.sbspro.2014.01.1423

[48] Lai, E. R. (2011). Critical Thinking: A Literature Review. Research Report. Pearson.

[49] Kim, K., Sharma, P., Land, S. M., \& Furlong, K. P. (2013). Effects of active learning on enhancing student critical thinking in an undergraduate general science course. Innovative Higher Education, 38(3), 223-235. https://doi.org/10.1007/s10755-012-9236-x

[50] Nold, H. (2017). Using critical thinking teaching methods to increase student success: An action research project. International Journal of Teaching and Learning in Higher Education, 29(1), 17-32. http://www.isetl.org/ijtlhe/

[51] Alwehaibi, H. (2012). Novel program to promote critical thinking among higher education students: Empirical study from Saudi Arabia. Asian Social Science, 8(11), 193-204. https://doi.org/10.5539/ass.v8n11p193

[52] Thurman, B. (2009). Teaching of critical thinking skills in the English content area in South Dakota public high schools and colleges. Education Resources Information Center. ERIC ED513229.

[53] Creswell, J. W. (2012). Planning, conducting, and evaluating quantitative and qualitative research (Fourth Edition). Boston: Pearson Education, Inc. ISBN 0131367390

[54] Liliia, K., \& Gulnara, G. (2016). Instagram: Mobile application in teaching EFL at university level mobile technologies in teaching English as a foreign language in higher education: A case study of using. In ICERI 2016 Proceedings 9th International Conference of Education, Research and Innovation November 14th-16th, 2016. https://doi.org/10.21125/ iceri.2016.0395

[55] Syarofi, A., Kuswahono, D., \& Rizky, H. (2018). Implementing process writing strategy using weblogs to improve students' ability in writing descriptive text. Lingua Cultura, 12(4), 351-355. https://doi.org/10.21512/lc.v12i4.4142

[56] Aziz, Z. A., \& Khatimah, H. (2019). Enjoying learning writing through facebook group. Lingua Cultura, 13(1), 115-119. https://doi.org/10.21512/lc.v13i1.5513

[57] Misır, H., Koç, D. K., \& Koç, S.E. (2018). An analysis of learner autonomy and autonomous learning practices in massive open online language courses. Arab World English Journal (AWEJ): Special Issue on CALL, 4, 24-39. https://doi.org/10.24093/awej/call4.3

[58] Ellis, R. A. \& Blius, A. M. (2017). Exploring new elements of the student approaches to learning framework: The role of online learning technologies in student learning. https:// doi.org/10.1177/1469787417721384

[59] Mao, S. S., \& Crosthwaite, P. (2019.) Investigating written corrective feedback: (Mis) alignment of teachers' beliefs and practice. Journal of Second Language Writing, 45(2019) 4660. https://doi.org/10.1016/j.jslw.2019.05.004 
[60] Dominique-Esther S, Sharon, R. Peled, Y., \& Yaffe, Y. (2019): Reflections on peer feedback in disciplinary courses as a tool in pre-service teacher training, Cambridge Journal of Education, https://doi.org/10.1080/0305764X.2019.1581134

[61] Kusumoto, Y. (2018). Enhancing critical thinking through active learning. Journal of Language Learning in Higher Education, 8(1), 45-63. https://doi.org/10.1515/cercles-2018$\underline{0003}$

[62] Suardana, I N., Redhana, I W., Sudiatmika, A. A. I. A. R., \& Selamat, I N. (2018). Students' Critical Thinking Skills in Chemistry Learning Using Local Culture-Based 7E Learning Cycle Model. International Journal of Instruction, 11(2), 399-412. https:// doi.org/10.12973/iji.2018.11227a

[63] Hidayati1, N., Zubaidah, S., Suarsini, E., Praherdhiono, H. (2019). Examining the relationship between creativity and critical thinking through integrated problem-based learning and digital mind maps. Universal Journal of Educational Research, 7(9A) 171-179. https://doi.org/10.13189/ujer.2019.071620

\section{Authors}

Haerazi was born in Gelang Lombok Tengah, Indonesia 1983. He is an English lecturer at Postgraduate of English Language education, FBMB UNDIKMA Mataram, Indonesia, since 2010. His research interests are focused on Teaching English as a Foreign Language (TEFL) issues and intercultural language learning models, the language and cultures, teaching of the four language skills, and Mobile-assisted language learning (MALL). He has published a number of articles related to teaching English as a Foreign Language and Teaching media. ORCID: 0000-0003-3933-4131

I Made Permadi Utama is an English lecturer at English Language education, FBMB UNDIKMA Mataram, Indonesia, since 2013. His research interests are focused on Teaching English as a Foreign Language (TEFL) issues and English language learning models, teaching of the four language skills, and Mobile-assisted language learning (MALL) for children. He has published several articles related to teaching English as a Foreign Language and Teaching media.

Heri Hidayatullah was born in Praya Lombok Tengah, 1982. He graduated his Master degree at State University of Malang in 2012. He is one of the lecturers at the English Language Education, Faculty of Language and Arts Education, Mandalika University of Education, West Nusa Tenggara, Indonesia, since 2007. His research interest is in the field of TEFL especially the Teaching of Reading and the Professional teachers. He has published some articles in either national or international journals.

Article submitted 2019-10-17. Resubmitted 2020-02-16. Final acceptance 2020-02-13. Final version published as submitted by the authors. 